\title{
Kepercayaan Diri dalam Peningkatan Keterampilan Komunikasi
}

\author{
Moch. Kalam Mollah \\ Institut Teknologi Adhi Tama Surabaya \\ Email: drs.kalamullah@yahoo.com
}

\begin{abstract}
Abstrak
Setiap individu memiliki kelebihan namun banyak yang tidak menyadarinya. Ini disebabkan kurang pekanya mereka terhadap potensi diri sendiri. Persoalan ini ditengarai berawal dari kurangnya kemampuan individu dalam berkomunikasi baik dengan orang lain maupun dirinya sendiri yang berkaitan dengan kepercayaan diri dalam menggambarkan identitas, jati diri, seseorang maupun pandangan orang lain terhadap sesuatu. Rasa percaya diri sejatinya hadir dalam pelbagai bentuk: Self confidence; efficacy; concept; maupun esteem. Untuk mendorong perkembangan hal tersebut diperlukan pelbagai hal, seperti keahliannya, auto sugesti; latihan; konsistensi; sikap cuek dan pengutaraan perasaan. Artikel ini hadir guna mengelaborasi pelbagai persoalan tersebut.
\end{abstract}

Kata kunci: komunikasi; self confidence; efficacy; concept; esteem.

\section{Pendahuluan}

Pendidikan formal memang sangatlah penting. Pendidikan juga sudah menjadi penopang dalam peningkatan sumber daya manusia untuk membangun bangsa. Karena di dalam pendidikan, siswa akan difasilitasi untuk mengembangkan kemampuan yang ada dalam diri mereka. Siswa akan mencari jati dirinya di dalam lingkungan pendidikan. Pendidikan juga membantu perkembangan jasmani dan rohani anak didik di luar lingkungan keluarga. Oleh sebab itu mutu terpenting dalam pendidikan merupakan upaya peningkatan sumber daya manusia yang terintegrasi. ${ }^{1}$ Di setiap sekolah pasti memiliki aturan-aturan atau kurikulum sekolah yang berbedabeda yang mana dengan secara otomatis visi misi dari setiap sekolah pun berbeda-beda, dan metode pembelajarannya juga berbeda-beda pula.

Kegiatan belajar mengajar seorang guru diharuskan untuk mengetahui sifat dan karakteristik siswa yang sesungguhnya, sehingga arahan yang akan diberikan guru kepada siswa tidak bertolak belakang, dan

\footnotetext{
1 Syarwani Ahmad, "Desain Pembelajaran SMA Plus Negeri 2 Banyuasin III Berbasis Karakter di Era Masyarakat Ekonomi Asean”, Jurnal Kajian Ilmu Pendidikan, vol. 2, no. 2 (2017), 4.
} 
siswa dapat memahami apa yang disampaikan gurunya sehingga terjalin komunikasi yang nyaman. Begitu juga dalam belajar mengajar mengenai mata pelajaran sekolahnya. Setiap siswa pasti memiliki pemahamanpemahaman yang berbeda ketika ia menangkap penjelasan dari guru yang mengajarnya. Oleh karena itu seorang guru juga harus mengetahui kekurangan dan kelebihan siswa ini berada dalam mata pelajaran apa dan mana yang kurang dipahami. Ketika siswa dihadapkan pada mata pelajaran yang tidak dimampunya seorang guru dapat memberi perhatian penuh atau memberi bimbingan khusus pada mereka yang memiliki kekurangan dalam nilai mata pelajaran tersebut. Seperti memberi tambahan jam untuk membahas kembali mata pelajarannya, memberi pertanyaan-pertanyaan atau sesuatu hal yang membuat dia tertarik dalam mata pelajaran yang menurutnya kurang mampu untuk difahami dan meggunakan metode-metode inovatif lainnya. Dengan demikian mereka akan merasa senang dan temotivasi serta penasaran dalam mata pelajaran yang dia rasa kurang mampu untuk difahami.

Jika hal tersebut terjadi dalam siswa Sekolah Menengah Atas (SMA) bagaimana untuk menyikapinya. Karena usia di jenjang ini remaja yang berada di periode akhir, sehingga kalau ada sedikit kesalahan dalam mendidik mereka, akan berakibat fatal karena mereka sudah bisa berfikir, mengkritik serta melawan yang tidak sesuai dengan apa yang mereka pahami dari beberapa pengalaman yang mereka dapat. Individu bisa dikatakan dewasa apabila telah mencapai usia 18 tahun (Hukum di amerika serikat saat ini), bukan di usia 21 tahun seperti ketentuan yang dikemukaan Hurlock. ${ }^{2}$ Fase di usia anak yang menduduki Sekolah Menengah Atas (SMA) biasanya kita sebut sebagai remaja yang memasuki fase untuk mencari jati diri, dalam fase ini mereka mengalami perkembangan yang pesat dalam aspek intelektual. Proses berfikirnya remaja yang pada umumnya sedang duduk di Sekolah Menengah Atas (SMA) ini memungkinkan mereka tidak hanya mampu mengintegrasikan dirinya ke dalam masyarakat dewasa, tetapi juga merupakan karakteristik yang paling menonjol dari semua periode perkembangan. ${ }^{3}$ Mereka juga tidak memiliki tempat yang jelas karena di usianya sudah tidak disebut anak kecil lagi, tetapi juga belum masuk dalam kategori dewasa.

\section{Definisi Percaya Diri}

Rasa percaya diri adalah sikap percaya dan yakin akan kemampuan yang dimiliki individu, yang dapat membantu seseorang untuk memandang dirinya dengan positif sehingga mampu bersosialisasi secara baik dengan orang lain. Percaya diri merupakan salah satu kekuatan jiwa yang sangat

\footnotetext{
${ }^{2}$ Moh Ali, et al., Psikologi Remaja (Jakarta: Bumi Aksara, 2005), 9.

${ }^{3}$ Ibid., 10.
} 
menentukan berhasil tidaknya seseorang tersebut dalam mencapai berbagai tujuan hidupnya. ${ }^{4}$ Memiliki rasa percaya diri memang tidak semudah membalikkan telapak tangan. Siswa juga membutuhkan kebiasan-kebiasaan tertentu dan melatih diri untuk bisa menimbulkan rasa percaya diri pada seseorang. Memang manusia pasti memiliki kekurangan tetapi jangan sekalikali mempunyai rasa minder akan kekurangan yang ada pada diri kita. Karena hal inilah yang akan membuat kita tidak memiliki semangat dan gairah untuk hidup.

Setiap individu juga pasti memiliki kelebihan tetapi banyak yang tidak sadar akan kelebihan yang ia miliki sehingga banyak pula orang merasa tidak percaya diri dengan orang-orang yang ada di sekitarnya disebabnya kurang peka terhadap potensi diri sendiri. Karena mereka memiliki pemikiran bahwa dirinya tidak mampu melakukan suatu hal. Rasa percaya diri ini juga tumbuh tergantung dengan sifat kepribadiannya. Jika individu kepribadiannya tertutup tidak menutup kemungkinan ketika ada masalah pada kehidupannya dia tidak akan memiliki keberanian untuk berbagi permasalahan ataupun pengalaman yang dimilikinya terhadap orangorang sekitar ataupun terdekat. Dia mempunyai rasa bahwa pengalaman kehidupannya tidak menarik untuk orang lain. Sehingga hal kecil yang dapat meningkatkan rasa percaya diri tidak dilewatinya dengan baik. Jika individu memiliki kepribadian yang terbuka, maka sedikit maupun banyak pengalaman yang dimilikinya dia akan berbagi kepada orang-orang disekitarnya karena mereka yang seperti ini memiiki pemikiran bahwa kita juga bisa belajar dari pengalaman jadi penting tidaknya pengalaman yang telah kita alami ia selalu menceritakan terutama dengan orang-orang terdekatnya sehingga dapat beajar bersama dari pengalaman agar di kemudian hari tidak terulang. Kepribadian juga merupakan perilaku manusia, yang pembahasannya terkait dengan apa, mengapa dan bagaimana individu dapat merespon keadaan di sekitarnya dengan ciri khasnya. ${ }^{5}$ Kepribadian juga menggambarkan identitas, jati diri seseorang, dan pandangan orang lain tentang diri seseorang, kemampuan seseorang dalam keterampilan bercakap, kualitas tingkah laku dari individu. ${ }^{6}$

Percaya diri juga memiliki beberapa macam kategori, yaitu sebagai berikut: a) self confidence, yakni sejauh mana individu punya keyakinan terhadap penilaian dirinya atas kemampuan yang dimilikinya dan sejauh mana individu bisa merasakan adanya "kepantasan" untuk berhasil. Self confidience ini juga memiliki makna yaitu rasa percaya diri terhadap

\footnotetext{
${ }^{4}$ Iceu Rohayati, Program Bimbingan Teman Sebaya untuk Meningkatkan Percaya Diri Siswa, Edisi Khusus no. 1 (Agustus, 2011), 32.

${ }^{5}$ Syamu Yusuf et al. Teori Kepribadian (Bandung: Reaja Rosdakarya, 2012), 1.

${ }^{6}$ Ibid., 3.
} 
kemampuan atau kesanggupan diri mencapai prestasi tertentu, ${ }^{7}$ contoh: Seorang siswa memiliki hobi bermain bulu tangkis hingga ia mahir dalam permainan bulu tangkis, dan siswa itu sadar akan kemampuannya. Sehingga ketika ia dimintai untuk mewakili sekolahnya di ajang perlombaan ia tidak akan menolak karena ia sadar akan kemampuan yang dimilikinya. b) self efficacy, yakni sejauh mana individu punya keyakinan atas kapasitas yang dimiliki untuk bisa menjalankan tugas atau menangani persoalan dengan hasil yang bagus, meyakini kapasitas dirinya di bidangnya dalam menangani urusan tertentu. Self efficacy juga memiliki arti lain yakni merupakan penilaian diri sendiri terhadap kemampuannya untuk menyusun tindakan yang dibutuhkan dalam menyelesaikan tugas-tugas khusus yang dihadapi, ${ }^{8}$ contoh: Individu adalah seorang yang memiliki tanggung jawab atas anggota-anggotanya, dan ketika dalam kelompok tersebut memiliki masalah, individu itu tidak segan-segan untuk mengajak merancang rencana yang baik untuk keluar dari masalah tersebut. c) self concept, yakni bagaimana anda menyimpulkan diri anda secara keseluruhan, mulai dari aspek secara fisik, mental dan keberaniannya, bagaimana anda melihat potret diri anda, dan bagaimana anda mengkonsepsikan diri anda secara keseluruhan, self concept ini terbentuk dari pengalaman individu tersebut bukan bawaan dari lahir. ${ }^{9}$ Self concept juga memiliki arti lain yaitu bagaimana individu itu melihat dirinya dan nilai apa yang ia pilih untuknya menjadi hal penting dalam menentukan tujuan-tujuan yang ia capai dari individu tersebut ketika mengingkan sesuatu ia merancang konsep dengan baik agar dapat memilikinya. ${ }^{10}$ contoh: siswa dalam memilih masalah tentang belajar ketika ia memiliki tekat untuk bisa, ia tidak segan-segan bertanya tentang apa yang belum mereka mengerti. d) self esteem, yakni penilaian terhadap diri sendiri, self esteem ini kombinasi yang berhubungan dengan karakter dan perilaku. Sejauh mana individu punya perasaan positif terhadap dirinya sendiri, sejauh mana individu punya sesuatu yang dirasakannya bernilai atau berharga dari diri individu tersebut, sejauh mana individu meyakini adanya sesuatu yang

7 Eva Dwi Minarti, et al., "Studi Komperatif Penerapan Pendekatan Kontekstual dan Pendekatan Kontekstual Bersetting Pembelajaran Cooperative Script terhadap Kemampuan Representasi Matematis dan Self Confidence Siswa SMK di Kota Cimahi”, Jurnal Ilmiah UPT STKIP Siliwangi, vol. 2, no. 2 (2015), 170.

${ }^{8}$ Hanny Ishtifa, "Pengaruh Self - Efficacy dan Kecemasan Akademis terhadap Self Regulated Learning Mahasiswa Fakultas Psikologi Universitas Islam Negeri Jakarta" (Skripsi--UIN Syarif Hidayatullah, Jakarta, 2011), 7.

${ }^{9}$ Rizqi Rahman, "Hubungan Self Concept terhadap Matematika dengan Kemampuan Berpikir Kreatif Matematika Siswa”, Jurnal Ilmiah Program Studi Matematika STKIP Siliwangi Bandung, vol. 1, no. 1 (2012), 15.

${ }^{10}$ Dwi Astuti Pratiwi, "Pembelajaran Berbasis Masalah (Problem Base Learning) dengan Metode Proyek dan Reitasi Ditinjau dari Kreativitas dan Konsep Diri (Self Concept) Siswa" (Tesis--Universitas Sebelas Maret, Surakarta, 2010), 49. 
bernilai, bermartabat atau berharga dalam diri individu tersebut. ${ }^{11}$ Self esteem juga memiliki makna lain yakni pelindung individu dari pengaruh sakit dan mencegah dari berbagai macam permasalahan hidup. Individu yang memiliki self esteem yang tinggi sikapnya secara sosial lebih dapat diterima dan bertanggung jawab, individu juga menjadi lebih mudah untuk bertahan pada lingkungan hidup yang dihadapi, dan pada akhirnya secara emosi sosioemosionalnya lebih baik. ${ }^{12}$ contoh: Seorang siswa yang memiliki kepercayaan yang tinggi pada dirinya ia merasa bahwa dirinya bukan hanya seorang anak, tetapi seorang anak yang baik.

Pola kepribadian merupakan citra seseorang tentang dirinya yang ada kaitannya dengan rasa percaya diri di setiap individu. Hal ini juga dipengaruhi oleh beberapa faktor, misalnya: dari faktor kedua orang tua, kondisi fisik, kematangan biologis, dampak dari media sosial, tuntunan sekolah, pengalaman ajaran agama, masalah ekonomi keluarga, hubungan dalam keluarga. Beberapa faktor-faktor tersebut akan banyak mempengaruhi dari kepriadian seseorang jika lingkungan di sekitarnya baik, seseorang tersebut akan terpandang baik. jika lingkungan seseorang itu buruk, maka tidak menutup kemungkinan orang tersebut akan dipandang buruk juga. Dapat dikatakan bahwa lingkungan memiliki peran utama untuk membentuk kepribadian seseorang. Kepribadian pun juga bisa berubah-ubah karena mungkin dipengaruhi dari beberapa faktor: a) Faktor fisik, seperti gangguan kesehatan misalnya gangguan otak, kurang gizi, mengkosumsi obat terlarang dan minuman keras. b) Faktor lingkungan sosial budaya, seperti krisis moneter, politik, stress, depresi, dan masalah sosial. c) Faktor diri sendiri, seperti tekanan emosional, identifikasi terhadap orang lain yang berkepribadian yang menyimpag. Tiga factor ini juga sangat berpengaruh ketika pembentukan kepribadian seseorang dimulai. Karena tiga faktor ini saling berkesinambungan satu sama lain. ${ }^{13}$

Rasa percaya diri pun juga berkaitan dengan karakter seseorang yang mana bahwa karakter ini juga menggambarkan kecenderungankecenderungan yang dipelajari untuk mengevaluasi situasi serta reaksi individu ketika menangkap situasi dengan cara-cara tertentu yang menjadi ciri khas dari individu tersebut. ${ }^{14}$ Karakteristik kepribadian juga dibagi menjadidua, diantaranya: a) kepribadian yang sehat, kepribadian yang sehat ditandai dengan: mampu menilai diri secara realistik, mampu menilai situasi secara realistik, mampu menilai prestasi yang diperolehnya, menerima

\footnotetext{
${ }^{11}$ Fitri Yulianto et al., "Kepercayaan Diri dan Prestasi Atlet Tae Kwon Do Daerah Istimewa Yogyakarta", Jurnal Psikologi Universitas Diponegoro. vol. 3, no. 1 (2006), 16.

${ }^{12}$ Muhammad Iqbal, "Hubungan antara Self Esteem dan Religiusitas terhadap Resiliensi pada Remaja di Yayasan Himmata" (Skripsi-- UIN Syarif Hidayatullah, Jakarta, 2011), 26.

${ }^{13}$ Yusuf, "Teori kepribadian", 11.

${ }^{14}$ Ibid., 10.
} 
tanggung jawab, kemandirian, dapat mengontrol emosi, memiliki rasa kepedulian, mampu bersosial, memiliki filsafat hidup, tidak merugikan orang lain dan berbahagia. ${ }^{15}$ b) kepribadian yang tidak sehat, Sedangkan ciri kepribadian yang tidak sehat, diantaranya: mudah marah, menunjukkan kekhawatiran dan kecemasan, sering merasa tertekan, bersikap kejam atau suka mengganggu orang lain di usianya yang lebih muda, ketidak mampuan untuk menghindar dari prilaku menyimpang meskipun sudah diberi peringatan ataupun terkena sangsi, sering membuat masalah di lingkungannya, merugikan orang lain, suka melanggar tata tertib, memiliki kebiasaan berbohong, hiperaktif, bersikap memusuhi semua bentuk otoritas, senang mengkritik dan mencemoh orang lain, sulit tidur, kurang memiliki rasa tanggung jawab, sering mengalami pusing kepala, kurang memiliki kesadaran untuk mentaati ajaran agama, bersikap pesimis dalam menghadapi kehidupan, kurang bergairah dalam menjalankan kehidupan sehingga terkadang memiliki rasa putus asa. ${ }^{16}$ Dari kepribadian yang tidak sehat ini membutuhkan tindak pencegahan itu sangatlah penting dilakukan baik dari pihak keluraga , lingkungan, sekolah, dan pemerintahan agar dapat menciptakan perkembangan potensi secara optimal baik yang menyangkut fisik, psikis, dan sosial. Dengan memberi semangat dan motivasi-motivasi yang membangun agar kehidupan seseorang yang tidak sehat tersebut bisa bangkit untuk merubah pola pemikirannya menjadi lebih baik lagi.

Penyebab seorang siswa tidak memiliki rasa percaya diri untuk berbicara di depan orang banyak: a) Kebiasaan belajar yang kurang baik, seperti halnya siswa hanya belajar sesuai jadwal sekolah dan itu pun tidak teratur, atau belajar ketika ada PR dan ujian. b) Kurangnya penguasaan komponen isi atau ketika berbicara ia kurang paham dengan apa yang teah dibicarakan. c) Sikap mental yang tidak memiliki keyakinan untuk bisa karena rendahnya motivasi yang membangun dirinya agar memiliki tekat untuk bisa. d) Rendahnya pengalaman tampil berbicara di depan umum. e.) Hubungan interaksi antara guru dan murid yang kurang ataupun hubungan dengan orang sekitar ppun juga kurang. f) Penggunaan metode mengajar yang hanya menggunakan metode ceramah, tidak menggunakan metode yang memiliki interaksi yang baik dengan siswa. g) Penggunaan media pembelajaran yang kurang yang mengakibatkan siswa tidak bersemangat untuk belajar. h) Hubungan interaktif antara siswa dan siswa lain yang kurang baik dan masih rendah, sehingga mengakibatkan keterampilan

\footnotetext{
${ }^{15}$ Ibid., 13-14.

${ }^{16}$ Ibid., 14.
} 
berbicaranya kurang. ${ }^{17}$ i) Adanya rasa cemas, gugup, dan keluar keringat dingin. j) Tidak memiliki target yang diperjuangkan secara sungguhsungguh. k) Tidak memiliki keputusan melangkah yang jelas dengan tujuan hidupnya. 1) Mudah frustasi ketika menghadapi masalah, dan sering memiliki harapan yang tidak realistis. ${ }^{18}$

\section{Keterampilan Berkomunikasi}

Keterampilan berkomunikasi merupakan kemampuan khas manusia yang paling sempurna dan mengagumkan, pada umumya dalam keterampilan berkomunikasi pada individu dengan kecepatan yang luar biasa ketika di awal masa kanak-kanak. Belajar berkomunikasi dengan sedemikian beragamnya bahasa dan sedemikian rumitnya susunan kata sehingga terkadang tampak seperti suatu hal yang ajaib. ${ }^{19}$ Karena dengan berbedabedanya bahasa itu membuatnya satu sama lain tidak dapat memahami apa yang dibicarakan sehigga kesulitan ketika berinteraksi. Berdasarkan para penelitian para ahli psikolog keterampilan berkomunikasi sebagai kemampuan individu dalam menguasai kosa kata, ucapan, gramatikal, dan etika pengucapkannya dalam kurun waktu tertentu sesuai dengan perkembangan umum dan kronologisnya. Karena dengan dapat menguasai dasar-dasar kata tersebut individu akan mudah untuk berinteraksi satu sama lain dan setiap bahasa biasanya memiliki ciri khas. Perbandingan antara umur dan kemampuan berkomunikasi dari individu itu dapat dilihat dari perkembangan bahasanya. ${ }^{20}$ Kemampuan dalam berbahasa merupakan hasil belajar individu dalam interaksinya dengan lingkungan. dari perkembangan bahasa ini dapat dilihat apakah individu dapat merespon apa yang ia dengar dengan baik atau tidak, dan dari sinilah dapat menilai dan mengukur kecerdasan yang diiliki individu serta daya ingatnya. Penguasaan bahasa juga berawal dari hasil perpaduan peristiwa peristiwa linguistik yang dialami selama masa perkembangannya yang terbentuk melalui proses pengondisian klasik, pengondisian operan dan belajar sosial. ${ }^{21}$

Secara umum, perkembangan keterampilan berbahasa pada idividu dibagi dalam empat komponen: a) Fonologi, ialah suatu kemampuan berbahasa yang berkaitan dengan bagaimana individu tersebut dapat menghasilkan, dan memperoleh fasilitas untuk memahami bunyi bahasa, bunyi kata dan intonasi. b) Semantik, ialah suatu kemampuan berbahasa yang bekaitan dengan makna atau cara yang mendasari konsep-konsep yang

17 I Putu Mas Dewantara, "Identifikasi Faktor Penyebab Kesulitan Belajar Keterampilan Berbicara Siswa dan Strategi Guru untuk Mengatasinya, Artikel Penelitian, Prodi Pendidikan Bahasa" (Mei, 2012), 7-11.

${ }^{18}$ Ibid., 13.

${ }^{19}$ Asrori, "Psikologi Remaja", 122.

${ }^{20}$ Ibid., 123.

${ }^{21}$ Ibid., 123. 
diekspresikan dalam kata-kata atau kombinasi kata. Hal ini juga dapat dilihat dari sejauh mana kekuatan individu untuk memahami ribuan pemetaan katakata ke dalam konsep yang dimiliki sebelumnya meskipun belum terlabelkan dalam dirinya dan kemudian menghubungkannya dengan kesepakatan dalam bahasa masyarakat. c) Grammar, ialah suatu kemamuan berbahasa yang berkaitan dengan penguasaan kosakata dan memodifikasikan cara-cara yang bermakna. Pengetahuan mengenai grammar sendiri meliputi dua aspek utama, yaitu: pertama, Sintak (syntax) merupakan aturan-aturan yang mengatur bagaimana kata-kata disusun ke dalam kalimat yang dapat dipahami. Kedua, Morfologi (morfology) merupakan aplikasi gramatikal yang meliputi jumlah, tenses, kasus, pribadi, gender, kalimat aktif, kalimat pasif, dan berbagai makna lain dalam bahasa. d) Pragmantik, ialah suatu kemampuan berbahasa yang berkaitan dengan sisi komunikatif dari bahasa dan bagaimnana mengambil kesempatan yang tepat, mencari dan menetapkan topik yang relevan, mengusahakan agar benar-benar komunikatif. (bagaimana suatu bahasa harus diucapkan dalam suatu kelompok masyarakat tertentu). ${ }^{22}$

Karakteristik perkembangan bahasa remaja telah mencapai tahap kompetisi lengkap. Pada usia ini, individu diharapkan telah mempelajari semua sarana bahasa dan keterampilan-keterampilan performasi untuk memahami dan menghasilkan bahasa tertentu dengan baik. Karakteristik perkembangan bahasa remaja juga didukung oleh perkembangan kognitif yang telah mencapai tahap operasional formal, dari sini remaja mulai mampu mengaplikasikan prinsip-prinsip berfikir formal atau berfikir secara ilmiah secara baik pada setiap situasi dan mengalami peningkatan kemampuan dalam menyusun pola hubungan kata secara komprehensif, membandingkan secara kritis antara fakta dan asumsi dengan mengurangi penggunaan simbol-simbol dan terminologi konkret dalam mengimplikasiannya. Dalam perkembangan masyarakat modern, terutama di daerah kota perkembangan bahasa khas remaja sering dikenal dengan bahasa gaul. Di kalangan remaja sendiri justru lebih akrab dan sangat memahami bahasa gaul serta merasa lebih aman jika berkomunikasi dengan sesama remaja dengan bahasa gaul. Mereka berfikir bahwa dengan menggunakan bahasa tersebut mereka lebih merasa dekat dan nyaman satu sama lain. meskipun bahsa itu menurut KBBI tidak sesuai. ${ }^{23}$

Faktor-faktor yang dapat mempengaruhi keterampilan berkomunikasi seseorang dapat juga ditentukan oleh faktor dari kedua orang tua. Jika orang tuanya pandai dalam berkomunikasi yang baik maka cepat perkembangan bahasanya idividu itu juga akan baik dan cepat, begitu juga

\footnotetext{
${ }^{22}$ Ibid., 123-124.

${ }^{23}$ Ibid., 127.
}

8 Jurnal El-Banat 
sebaliknya. Adapun keterampilan berkomunikasi yang dipengaruhi oleh factor lingkungan dan bawaan. Secara rinci terdapat beberapa factor yang mempengaruhi dalam perkembangan bahasa: a) Kognisi, tinggi rendahnya kemampuan atau kecerdasan individu akan mempengaruhi cepatnya perkembangan bahasa individu. Hal ini dapat dilihat dari individu tersebut atau bisa disebut dengan bawaan individu. bawaan individu ini juga berkaitan dengan gen orang tua, sehingga ketika orang tua memiliki gen yang baik, anak pun akan ikut baik, begitu juga dengan sebaliknya. b) Pola komunikasi dalam keluarga, dengan mengajak berkomunikasi tentang apa saja dan mendapat respon yang baik dalam berbicara pada individu tersebut. c) Jumlah anak atau anggota keluarga, jika jumlah anggota banyak akan lebih cepat dalam perkembangan bahasanya, karena lebih banyak komunikasi yang bervariasi, dibandingkan dengan mereka yang memiliki keluarga tunggal dan tidak ada anggota keluarga lain selain keluarga inti. serta komunikasi yang dialami individu juga lebih sering dilakukan dari pada anak tunggal. d) Posisi urutan kelahiran, perkembangan bahasa anak sulung lebih cepat dari pada perkembangan bahasa anak di tengah atau bungsu. Karena anak sulung sudah memiliki pengalaman berkomunikasi lebih luas dan sudah bertatap muka dengan banyak orang dari pada dari adik-adiknya, sehingga komunikasi pada anak sulung ini lebih bervariatif. e) Kedwibahasaan (Menggunakan lebih dari satu bahasa), anak yang dibesarkan dalam keluarga yang menggunakan bahasa lebih dari satu akan lebih bagus dan lebih cepat perkembangan bahasanya ketimbang yang hanya menggunakan satu bahasa karena anak terbiasa menggunakan bahasa secara bervariasi. f) Rasa percaya diri yang kurang. ${ }^{24}$

Perbedaan individu dalam keterampilan berkomunikasi secara kuat dipengaruhi oleh kematangan genetikal. Para ahli berkeyakinan bahwa kematangan secara genetikal akan sangat menentukan kompetisi berbahasa seseorang, faktor bawaan juga sebagai sarana penguasaan bahasa memungkinkan anak mampu mengombinasikan kata-kata kedalam ucapanucapan yang memiliki konsistensi gramatikal serta mampu memahami pembicaraan orang lain pada usia dini. seperti halnya ketika orang tua menggunakan dua bahasa, kosakata yang dimiliki anak tersebut juga lebih banyak dibandingkan yang menggunakan satu bahasa. ${ }^{25}$ Perkembangan kemampuan dalam berbahasa merupakan perpaduan dari faktor bawaan dan proses belajar dari lingkungan. Interensi pendidikan yang dilakukan secara terencana dan sistematis menjadi sangat penting. Mengandalkan faktor bawaan dari orang tua adalah keputusan yang tidak bijaksana karena hasilnya yang kurang memuaskan. Intervensi pendidikan yang melalui

\footnotetext{
${ }^{24}$ Ibid., 129.

${ }^{25}$ Ibid., 130.
} 
proses belajar dari lingkungan dapat diupayakan dengan memberikan kesempatan seluas-luasnya untuk keterampilan berkomunkasi secara optimal. Lingkungan yang memberikan kesempatan bagi anak untuk belajar dengan berlatih mengembangkan kemampuan bahasa perlu dikembangkan secara maksimal, baik dalam lingkungan keluarga, sekolah maupun masyarakat, agar kemampuan berbahasa remaja dapat berkembang secara optimal. ${ }^{26}$

Sejak dini anak juga perlu diperkenalkan dengan lingkungan yang memiliki kemampuan berbahasa yang variatif. Situasi yang menunjang perkembangan bahasa juga perlu diciptakan dan dikembangkan oleh para guru disekolah agar memiliki keterampilan dalam berkomunikasi. Di sisi lain masyarakat sangat perlu menciptakan suasana yang dapat membesarkan hati atau mendorong anak untuk berani mengkomunikasikan pikiranpikirannya. Demikian itu adalah cara yang sangat membantu perkembangan bahasa remaja karena mereka lebih leluasa dan tidak dihantui oleh kecemasan dan ketakutan untuk mengkomunikasikan apa saja yang sedang dipikirkannya. ${ }^{27}$ Disamping itu rasa percaya diri juga dapat menjadikan faktor terhambatnya keterampilan bahasa. Dapat kita ketahui bahwasannya orang yang kurang percaya diri dia lebih memilih untuk diam dari pada berinteraksi dengan orang lain termasuk dalam bentuk berkomunikasi. ${ }^{28}$

Keterampilan berkomunikasi juga bisa dapat dipengaruhi dari faktor intelektual seseorang serta kreatifitasnya seseorang. Karena intelektual ini adalah perkembangan kognitif individu dan kreatifitas ini yang mendukung dari kemampuan individu untuk lebih bevariatif dalam bahasa yang digunakan untuk berkomunikasi. Perkembangan intelektual pada masa remaja dapat diartikan dengan perubahan-perubahan yang terjadi pada kuantitas dan kualitas kinerja akal. ${ }^{29}$ Sebab kemampuan akal dapat berkembang dengan lebih cepat bila dibandingkan dengan fase-fase sebelumnya ketika ia belum menginjak usia remaja, dimana kematangan akal di fase remaja ini menjadi lebih sempurna dari pada fase sebelumnya. Perkembangan kemampuan akal ini menjadi faktor yang terpenting dalam membantu remaja beradapasi antara dirinya dan lingkungan sosialnya. Ketika kita akan mengkomunikasikan apa yang ingin dibicarakan sebelum kalimat tersebut diucapkan alangkah lebih baiknya dicerna terlebih dahulu di dalam akal (berfikir) agar ucapan yang kita sampaikan akan memahamkan bagi pendengarnya serta menjauhkan dari kesalah fahaman. Berfikir

\footnotetext{
${ }^{26}$ Ibid., 131.

${ }^{27}$ Ibid., 132.

${ }^{28}$ Ibid., 134.

${ }^{29}$ Sayyid al-Za'balawi, Pendidikan Remaja antara Islam dan Ilmu Jiwa, terj. Abdul Hayyi alKattani (Depok: Gema Insani, 2007), 45.
}

10 Jurnal El-Banat 
merupakan operasi yang dilakukan oleh akal. Permulaan proses ini terjadi pada masa balita dan terus mengalami pertumbuhan. Dia sudah dapat meneliti fakta-fakta yang ada di lingkungannya dan menelaah dari objek yang mereka hadapi, berusaha menyingkap dan mengetahui berbagai hal, secara bertahap dari bagian kecil menuju ke total keseluruhan. ${ }^{30}$

\section{Rasa Percaya Diri Berdampak pada Keterampilan Berbahasa}

Rasa percaya diri adalah kunci seseorang dapat berkomunikasi serta berinteraksi dengan orang-orang sekitar. Meskipun di awal belajar untuk berkomunikasi dengan orang lain terutama yang menggunakan bahasa asing tidak saling memahami, dengan berjalannya waktu ketika kita lebih sering berinteraksi dengan mereka kita akan merasa terbiasa dan secara otomatis komunikasi di antara keduanya bisa saling memahami satu sama lain karena sudah terbiasa. Karena dengan pembiasaan ini bahasa-bahasa yang bervariatif yang digunakan untuk berkomunikasi ini dengan mudahnya akan kita ingat dan diucapkan. ${ }^{31}$

Kepribadian seseorang juga dapat mepengaruhi rasa percaya diri terhadap individu. Ketika individu ini memiliki kepribadian rasa sosial yang tinggi tidak menutup kemungkinan rasa percaya dirinya terhadap lingkungan sosial juga sangat tinggi, begitu juga sebaliknya. Karena di kehidupan sosial juga membeutuhkan interaksi yang baik agar dapat memahami satu sama lain. Sehingga kepribadian dan rasa percaya diri ini memiliki kesinambungan yang selaras ketika akan menjalin interaksi yang baik. ${ }^{32}$

Kepribadian yang tidak sehat tersebut juga menjadi hambatan untuk memiliki rasa percaya diri. Adapun masalah-masalah yang dialami individu yang kurang percaya diri, diantaranya: a) Minder terhadap orang yang lebih hebat darinya. b) Merasa tidak memiliki kelebihan. c) Kurangnya kemampuan dalam berkomunikasi atau berbahasa. d) Tidak yakin dengan kemampuan dan kelebihan yang dimiliki. e) Motivasi yang kurang. f) Tidak begitu menguasai dalam bidangnya. g) Penguasaan komponen kebahasaan yang kurang, yang menyangkut lafal, nada intonasi, durasi, diksi, struktur kebahasaan, gaya bahasa yang masih sangat rendah. ${ }^{33}$

Keterampilan berkomunikasi menjadi salah satu tolak ukur rasa percaya diri seseorang. Jika keterampilan berkomunikasinya baik, maka rasa percaya diri yang dimiliki individu tersebut juga baik. Jika keterampilan berkomunikasinya kurang, maka individu tersebut memiliki rasa percaya diri yang kurang. Rasa percaya diri ini akan berdampak pada masalah keterampilan berkomunikasi. Karena keterampilan berkomunikasi ini cara

\footnotetext{
${ }^{30}$ Ibid., 49.

${ }^{31}$ Ibid., 51.

${ }^{32}$ Ibid., 55.

${ }^{33}$ Ibid., 50.
} 
bagaimana ia mengekspresikan dirinya di hadapan umum, bagaimana ia menyampaikan apa yang ia ketahui dengan bahasannya sendiri. ${ }^{34}$

\section{Kesulitan Dalam Komunikasi Berbahasa Asing}

Peran guru disini bagaimana dia berusaha untuk membantu siswa dalam pengembangan kehidupan pribadi, kehidupan sosial, dan yang paling utama dalam permasalahan belajar siswa. Pelayanan yang seharusnya dimiliki guru khususnya guru bimbingan konseling, dia dituntut untuk mampu memfasilitasi pengembangan siswa secara individual, kelompok, atau klasikal, sesuai dengan kebutuhan, potensi, bakat minat, perkembangan, kondisi, serta peluang-peluang yang dimiliki siswa tersebut untuk menuju kehidupan yang layak. Peran guru sangat penting untuk siswanya karena guru adalah seseorang yang dapat mendampingi siswa ketika berada dilingkungan sekolah terutama dalam beberapa hal diantaranya: a) dalam pengembangan belajar di sekolah. b) mengenal diri sendiri dan mengerti kemungkinan-kemungkinan yang terbuka bagi siswa, baik untuk dimasa sekarang ataupun kelak. c) menentukan cita-cita dan tujuan dalam hidup, serta menyusun rencana yang tepat untuk mencapai tujuan-tujuan itu. d) mengatasi masalah pribadi yang menganggu belajar di sekolah dan hal-hal yang dapat menguburkan cita-citanya. ${ }^{35}$

Membina hubungan baik antara konselor dan klien itu sangat diperlukan agar konseling dapat berjalan dengan efektif. Apabila di antara keduanya memiliki hubungan yang baik mereka akan merasa nyaman satu sama lain, sehingga ketika mereka menyampaikan permasalahannya akan merasa tidak ada perasaan tertekan di antara keduanya. Jika sebaliknya apabila konselor dan konseling tidak memiliki hubungan yang baik, maka proses berjalannya konseling akan terasa pincang. Membina hubungan yang baik pun juga membutuhkan cara-cara tertentu untuk memulainya. Apalagi kalau antara konselor dan klain tidak mengenal satu sama lain. Dengan demikian konselor disini menggunakan Pendekatan Realitas. Pendekatan Realiatas adalah melibatkan diri dengan klien dan mendorong klien untuk menghadapi kenyataan dan membuat pertimbangan nilai mengenai tingkah lakunya sekarang yang di kemudian hari ada perubahan perubahan yang ingin dilakukan oleh klien. ${ }^{36}$ Dari kedua pendekatan ini konselor mencoba untuk memberi beberapa konseling tentang permasalahan mereka kemudian konselor membantu membimbingnya secara perlahan, dan di kemudian hari konselor melakukan konseling lagi untuk mengetahui hasil yang telah

\footnotetext{
${ }^{34}$ Ibid., 53.

35 Sri Helma Hidayati, "Peran Guru Bimbingan dan Konseling dalam Mengidentifikasi Permasalahan Belajar Peserta Didik di SMA Negeri Kandangan", Jurnal Mahasiswa BK AnNur: Berbeda, Bermakna, Mulia, vol. 3 no. 2, 2017, 2.

${ }^{36}$ Hidayati, "Peran Guru Bimbingan", 4.
} 
mereka capai, Apakah mereka sudah berusaha melakukan suatu hal yang belum mereka lakukan sebelumnya. Dengan demikian kegiatan ini menjadi kegiatan baru bagi mereka agar permasalahan yang mereka alami hasilnya sesuai ekspetasinya. ${ }^{37}$

Disini ketika konselor mengambil sempel dari perwakilan Remaja yang duduk di bangku Sekolah Menengah Atas. Tepatnya pada hari Selasa 2 Oktober 2018. Mewawancarai beberapa siswa SMA diantaranya: a) klien satu, Anisa Ulifatun Hidayah, jurusan IPA, kelas X, Nama Sekolahnya SMA 1 Muhammadiyah Sepanjang Taman, Sidoarjo. Dia memiliki masalah dalam mata pelajaran bahasa inggris. Metode pembelajaran guru di sekolahnya hanya menggunakan metode transliterasi saja sehingga kemampuan untuk mengkomunikasikan bahasa itu tidak dipraktekkan. Bahkan ia pernah memanggil guru privat untuk khusus belajar berbahasa inggris tetapi tetap tidak ada hasil yang ia peroleh. Metode yang digunakan sama dengan guru di sekolahnya. Sehingga ketika Anisa berkomunikasi dengan berbahasa dia tidak berani karena ragu akan pelafalan yang diucapkan. ${ }^{38}$ b) Klien dua, Ine Agatha Cahyani, SMK YPM 2 Taman Sidoarjo, jurusan tataboga. Dia memiliki permasalahan belajar pada mata pelajaran bahasa mandarin. Dari kesulitan itu dia menyukai mata pelajaran tersebut. Sehingga tidak ada gairah untuk belajar bahasa mandarin apalagi untuk belajar berkomunikasi dengan bahasa tersbut. Karena kurangnya motivasi. ${ }^{39} \mathrm{c}$ ) klien ke-tiga, Bunga Permata, dari sekolah SMK 10 November Gedangan Sidoarjo, jurusan farmasi. Dia memiliki masalah belajar dalam mata pelajaran bahasa jepang. Tetapi usahanya dalam belajar bahasa jepang tetap disempatkan untuk belajar, meskipun ia memiliki nilai yang tidak memuaskan. Tetapi dalam urusan berkomunikasi dalam bahasa jepang juga tidak memiliki keberanian, melihat kemampuan teman-temannya yang jauh lebih baik darinya membuat dia merasa kurang percaya diri. ${ }^{40}$

Sehingga dapat disimpulkan anak-anak SMA ini dari hasil konseling ialah mereka kesulitan dan mempunyai masalah dalam sekolahnya di mata pelajaran bahasa serta kurangnya percaya diri dalam berkomunikasi terutama bahasa asing. Padahal dorongan motivasi-motivasi yang dilakukan gurunya di sekolahan juga sangat bagus tetapi metode yang digunakan kurang cocok dengan mereka. Mungkin karena kurangnya pembiasaan untuk mengucapkan bahasa-bahasa yang menjadi permasalahan mereka. Sehingga ketika dia mengucapkan dengan bahasa asing itu mereka merasa ragu dan kurang percaya diri akan kemampuan yang dimilikinya. Nilai mata pelajaran

\footnotetext{
37 Ibid., 7.

38 Anisa Ulifatun Hidayah, Wawancara (Sidoarjo, Oktober 2018)

${ }^{39}$ Ine Agatha Cahyani, Wawancara (Sidoarjo, Oktober 2018)

${ }^{40}$ Bunga Permata, Wawancara (Sidoarjo, Oktober 2018)
} 
bahasa asing ini masuk pada kategori yang paling rendah di antara mata pelajaran yang lain. Dengan demikian di permasalahan ini konselor sedikit mencoba untuk membantu mereka agar permasalahan yang mereka alami segera terselesaikan. Dari ketiga klain yang telah melakukan konseling mereka kesulitan dalam pengucapan bahasa asing dengan bahasa yang berbeda-beda pula. Sehingga guru bahasa di sekolahnya harus benar-benar membimbingnya dengan baik.

Usaha yang perlu dilakukan dalam rangka meningkatkan percaya diri siswa adalah dengan mengoptimalkan berbagai layanan bimbingan dan konseling kepada siswa. ${ }^{41}$ Adapun cara lain untuk meningkatkan percaya diri, di antaranya: a) Menguasai pekerjaan atau keahliannya. b) Auto sugesti (motivasi diri kalau dia pasti bisa). c) Melatih diri dari hal yang kecil. ${ }^{42} \mathrm{~d}$ ) Pengulangan, yang konsisten biasanya disebut istiqomah. e) Jangan hiraukan perkataan orang lain yang memiliki pikiran negative terhadap diri kita dan jadikan hal itu sebagai motivasi diri. f) Belajar mengeluarkan apa yang ada di hati dengan ucapan dan berkomunikasi yang baik dengan lingkungan sekitar. (belajar berbicara). g) Memiliki perspektif bahwa semua orang adalah sama. h) Murah senyum yang selebar-lebarnya dan melatih diri untuk menatap mata orang lain. Agar ketika berbicara saling berkesinambungan dan merasa nyaman. ${ }^{43}$

\section{Cara Meningkatkan Komunikasi Berbahasa Asing}

Dari hasil konseling permasalah yang ada pada siswa SMA ialah kekurangannya dalam berkomunikasi terutama dengan berbahasa asing. Pembelajaran ini menggunakan metode guru sebagai peran penting yang diharuskan memiliki kemampuan konseling dan bertindak sebagai konselor bahasa, dan pembelajaran komunitas bahasa menempatkannya menjadi peserta didik sebagai klien dalam bimbingan konseling. Guru yang sebagai konselor harus meningkatkan semangat siswa dengan terus memberi motivasi belajar, khususnya dalam belajar bahasa asing serta mengatasi masalah klien dengan hubungan yang nyaman dan pemahaman untuk mengatasi kesulitan dalam berbahasa, adapun lima tahapan langkah adaptasi untuk mengembangkan pembelajaran bahasa, di antaranya:

Tahap pertama, peserta didik bergantung penuh dengan guru. Langkah-langkahnya ialah: a) Peserta didik mengatakan pada guru di sekolahnya tentang apa yang ingin disampaikannya pada kelompok belajarnya. Temannya boleh mendengarkan, namun tidak terlibat dalam interaksi dengan guru. Jadi ketika siswa memiliki ide mengenai tema yang

\footnotetext{
${ }^{41}$ Rohayati, "Program Bimbingan Teman Sebaya untuk Meningkatkan Percaya Diri Siswa", 28.

${ }^{42}$ Ibid., 30.

${ }^{43}$ Ibid., 32 .
}

14 Jurnal El-Banat 
akan dibahas dengan kelompoknya siswa hanya bisa memberi tahu tem tersebut kepada guru dan guru hanya bisa menyaksikan saja tidak boleh membatu siswa. b) guru merefleksikan ide tersebut pada siswa menggunakan bahasa asing (yang sudah dipelajari) secara lembut dengan menggunakan bahasa sederhana, satu frasa yang terdiri dari lima atau enam kata. c) peserta didik kembali ke kelompoknya dan menyatakan idenya menggunakan bahasa asing. guru dapat membantu siswa jika ada ucapan yang keliru atau kata yang salah saja. ${ }^{44}$

Tahap kedua, peseta didik dilatih untuk mandiri, langkahlangkahnya ialah: a). peserta didik mengatakan pada guru (menggunakan bahasa Indonesia) tetang apa yang ingin disampaikannya pada kelompok belajarnya (melapor materi yang akan dibahas dengan teman kelompoknya). b). Siswa kembali ke kelompoknya dan memulai berbahasa asing secara langsung pada temannya. c). Guru hanya membantu jika siswa kesulitan atau meminta bantuan hanya dalam kosakata bahasa yang kurang tepat saja. dari sini siswa sudah mulai dilatih untuk mandiri agar menumbuhkan rasa percaya diri siswa ketika berbahasa asing. ${ }^{45}$

Tahap tiga, latihan mengungkapkan pernyataan. Langkahlangkahnya ialah: a). Siswa berbicara secara langsung pada kelompok menggunakan bahasa asing yang dipelajari. Pada tahap ini anggota kelompok dianggap memahami frasa sederhana yang diucapkan oleh siswa yang mengikuti konseling pada guru. Jika tidak faham boleh meminta untuk diulangi kata bahasa asing tersebut hingga teman kelompo seluruhnya paham materi yang dibahas. b). Guru hanya membantu jika siswa kesulitan atau meminta bantuan dalam kosakata bahasa yang kurang tepat. Peserta didik dianggap memiliki rasa percaya diri, mulai mandiri, dan mampu mengkaitkan ide dengan frasa dan tata bahasa. Bantuan akan diberi ketika kelompok membutuhkan. ${ }^{46}$

Tahap empat, latihan menggunakan kalimat sempurna. Yang tahap tiga adalah mengungkapkan pernyatakan hanya dengan satu frasa yang hanya terdiri maksimal enam kata. Pada langkah ke empat ini, siswa dituntut untuk menggunakan kalimat ang sempurna. Langkah-langkahnya ialah: a) Siswa berbicara secara bebas menggunakan kalimat yang lebih kompleks dalam berbahasa asing yang dipelajari. b) Guru melakukan koreksi terhadap kekeliruan penggunaan tata dalam bahasa, pengucapan, atau jika siswa membutuhkan bantuan dalam menyatakan kalimat kompleks. Disini siswa akan terbiasa untuk mengucapkan kalimat-kalimat berbahasa asing, sehingga

\footnotetext{
${ }^{44}$ Ridwan Abdullah, Inovasi Pembelajran (Jakarta: Bumi aksara, 2013), 5.

${ }^{45}$ Ibid., 6.

${ }^{46}$ Ibid., 7.
} 
akan mempermudahkan siswa untuk berkomunikasi dengan bahasa tersebut. ${ }^{47}$

Tahap lima, siswa berlatih membimbing teman. Langkah-langkanya ialah: a) Peserta didik berbicara secara bebas menggunakan kalimat yang lembut kompleks dalam bahasa asing yang dipelajari. b) Guru melakukan koreksi dan menambah idiom atau frase. c) si swa belajar menjadi konselor untuk temannya yang membutuhkan, dan menjalankan tahap satu sampai tiga. $^{48}$

Metode membaca, juga sangat diperlukan ketika kita ingin belajar berbahasa asing. Sebab metode ini dapat digunakan untuk mengembangkan kemampuan siswa dalam membaca dan memahami bahasa asing secara lebih mudah. Jika ada kata-kata yang sulit dipahami ketika membaca ia dapat mencari maknanya terlebih dahulu. Kemudian melanjutkan membacanya. Adapun prosedur membaca, diantaranya: a) Pada tahap awal kegiatan di minggu pertama belajar dimulai dengan latihan ucapan yang dikhususkan untuk menyimak sebagai upaya membiasakan peserta didik berbicara dan memahami kalimat. b) kemudian peserta didik mulai fokus pada membaca dengan tujuan memahami bacaan dengan cara memperbanyak pertanyaanpertanyaan pemahaman. Aktivitas ini dilakukan secara bertahap melalui teks dan buku-buku untuk membuat peserta didik memiliki kekayaan dan variatif dalam berbahasa. ${ }^{49}$

Metode Audio Lingul, kegiatan belajar mengajar ini pada umumnya menggunakan pendekatan oral. Ciri khas dari pedekatan oral ialah meniru dan mengingat. Metode ini berorientasi pada hasil analisa struktur bahasa antara bahasa yang digunakan setiap hari dan bahasa yang dipelajarinya di sekolah. Metode ini dapat digunakan untuk meningkatkan kemampuan siswa dalam menguasai keterampilan berbahasa, yakni Menyimak, Berbicara, Membaca, dan Menulis. Metode audio lingual secara umum biasanya sebagai berikut; (a) Tahapan lisan murni dimulai dari dua hingga tiga minggu yang bertujuan untuk melatih pendengaran dengan ucapan, dimana guru melakukan proses percakapan berdasarkan aktivitas kehidupan seharihari dengan bantuan gambar dan peraga. (b) Tahapan permulaan membaca, dimana siswa mulai membaca teks perakapan yang pernah mereka dengar dan mereka latihkan bahkan dihafalkan. Tulisan dipelajari secara bertahap dalam tahapan membaca. jika pelajaran membaca menggunakan metode audio yang bebasis buku teks yang dapat dilakukan, ialah: a) mendengar dengan keadaan buku tertutup. b) mendengar dengan mengulang dengan keadaan tertutup. c) mendengar dengan keadaan buku dibuka (menghubunga

\footnotetext{
${ }^{47}$ Ibid., 8.

${ }^{48}$ Ibid., 9.

${ }^{49}$ Ibid., 11.
}

16 Jurnal El-Banat 
bunyi dengan tulisan). d) membaca bersama-sama dengan keadaan buku terbuka. e) membaca berkelompok dengan keadaan buku terbuka. f) membaca individual dengan keadaan buku terbuka. g) menjawab pertanyaan-pertanyaan untuk mengoreksi pemahaman. h) latihan pola kalimat. ${ }^{50}$

Jika melatih pola ucap kalimat yang perlu dilakukan yaitu memperhatikan prinsip-prinsip sebagai berikut: a). Latihan pola kalimat dilakukan dalam tempo yang sesuai dengan keadaan. b). Latihan dilakukan secepat mungkin untuk membiasakan dan memantapkan peserta didik mengucapkan kalimat berbahasa asing. c). Guru berbicara dengan kecepatan yang wajar atau alami sesuai dengan situasi atau kondisi komunikasi sebenarnya. d). Kosakata baru diajarkan melalui pemakaian pola kalimat yang diajarkan sebelumnya. e). Pemakaian pola kalimat di luar yang telah diajarkan bukan hal yang salah. Kata-kata baru harus dajarkan pengertiannya. f). Latihan sebaiknya mengikuti pola diantaranya fokus (misalnya dengan menulis di papan tulis), memberikan contoh (dengan mengucapkan kalimat yang dicontohkan atau dimodelkan), penjelasan, (jika dibutuhkan penjelasan sederhana tentang tata bahasa), latihan di setiap harinya. ${ }^{51}$

Dari beberapa metode yang telah disebutkan di atas klien harus mengimbangi dengan mencari apa yang menjadi jati dirinya dan kemudian dikembangkan, serta buatlah klien berfikir bahwa diri anda pasti bisa, klien adalah seorang yang hebat. Jangan sampai klien mempertanyakan yang ada dalam dirinya seperti halnya, memiliki rasa bahwa saya tidak mampu, bahwa saya bodoh, dan apa kelebihan saya.

Berbagai hasil konseling yang telah konselor sampaikan kepada klien. Tepatnya pada tanggal 26 September 2018. Konselor melakukan konseling kembali untuk menanyakan hasil dari konseling. Mereka pun sedikit merasakan perubahan dari nilai-nilainya yang sebelumnya, yang mana sebelumnya memiliki nilai yang kurang memuaskan hingga memiliki nilai yang cukup. Meskipun nilai yang mereka dapat masih jauh dikata sempurna setidaknya nilai yang mereka peroleh saat ini lebih baik dari nilai bahasa sebelumnya. Serta dalam kemampuan berkomunikasi meskipun tidak mahir dalam bahasa tersebut setidaknya dia sudah berani untuk mengeluarkan sedikit kemampuannya, agar terbiasa dan tidak canggung dalam berkomunikasi terutama dalam bahasa asing. Serta memberikan motivasi bahwa permasalahan yang mereka alami belum seberapa berat. Memberi pengetahuan tentang berbagai solusi yang telah mereka ketahui untuk menyelesaikaan masalah-masalah mereka hingga klien menyadari

\footnotetext{
${ }^{50}$ Ibid., 12.

${ }^{51}$ Ibid., 13.
} 
tentang keindahan hidup, bahwa ketika ada kehidupan disitu pasti ada kematian ada tanggung jawab serta hal-hal kecil lain yang menjadi bukti bahwa kehidupan yang kita alami adalah nikmat yang luar biasa. Sehingga ia masih memiliki rasa bersyukur dan semangat untuk menjalankan hidup serta pantang menyerah.

\section{Penutup}

Rasa percaya diri adalah sikap percaya dan yakin akan kemampuan yang dimiliki individu, yang dapat membantu seseorang untuk memandang dirinya dengan positif dan realistis sehingga mampu bersosialisasi secara baik dengan orang lain. Percaya diri juga memiliki beberapa macam, yaitu sebagai berikut: a) Self confidence. b) Self Efficacy. c) Self Concept. d) Self esteem. Penyebab seorang siswa tidak memiliki rasa percaya diri untuk berbicara di depan orang banyak: a) Kebiasaan belajar yang kurang baik. b) Kurangnya Penguasaan komponen Isi. c) kurangnya pemahaman terhadap unsur kebahasaan dan non kebahasaan yang berpengaruh dalam pembelajaran keterampilan berbicara. d) Rendahnya pengalaman tampil berbicara di depan umum. e.) Hubungan interaksi antara guru dan murid yang kurang. f) Penggunaan metode mengajar. g) Penggunaan media pembelajaran yang kurang, mengakibatkan siswa tidak bersemangat untuk belajar.

Usaha yang perlu dilakukan dalam rangka meningkatkan percaya diri siswa adalah mengoptimalkan berbagai layanan bimbingan dan konseling kepada siswa. Adapun cara lain untuk meningkatkan percaya diri, di antaranya: a) Menguasai pekerjaan atau keahliannya. b) Auto sugesti (motivasi diri kalau dia pasti bisa). c) Melatih diri dari hal yang kecil. d) Pengulangan, yang konsisten biasanya disebut istiqomah. e) Jangan hiraukan perkataan orang lain yang memiliki pikiran negative terhadap diri kita dan jadikan hal itu sebagai motivasi diri. f) Belajar mengeluarkan apa yang ada di hati dengan ucapan dan berkomunikasi yang baik dengan lingkungan sekitar. (belajar berbicara). Remaja yang sedang menduduki bangku SMA ini dapat disimpulkan dari hasil konseling ialah mereka kesulitan dan mempunyai masalah dalam sekolahnya di mata pelajaran bahasa serta kurangnya percaya diri dalam berkomunikasi terutama bahasa asing. Padahal dorongan motivasi-motivasi yang dilakukan gurunya di sekolahan juga sangat bagus tetapi metode yang digunakan kurang cocok dengan mereka. Mungkin karena kurangnya pembiasaan untuk mengucapkan bahasa-bahasa yang menjadi permasalahan mereka.

Jika melatih pola ucap kalimat yang perlu dilakukan, maka harus memperhatikan prinsip-prinsip sebagai berikut: a. Latihan pola kalimat dilakukan dalam tempo yang sesuai dengan keadaan. b. Latihan dilakukan secepat mungkin untuk membiasakan dan memantapkan peserta didik 
mengucapkan kalimat berbahasa asing. c. Guru berbicara dengan kecepatan yang wajar atau alami sesuai dengan situasi atau kondisi komunikasi sebenarnya. d. Kosakata baru diajarkan melalui pemakaian pola kalimat yang diajarkan sebelumnya. e. Pemakaian pola kalimat di luar yang telah diajarkan bukan hal yang salah. Kata-kata baru harus dajarkan pengertiannya. f. Latihan sebaiknya mengikuti pola diantaranya fokus (misalnya dengan menulis di papan tulis), memberikan contoh (dengan mengucapkan kalimat yang dicontohkan atau dimodelkan), penjelasan, (jika dibutuhkan penjelasan sederhana tentang tata bahasa), latihan di setiap harinya.

Dari beberapa metode yang telah disebutkan di atas klien harus mengimbangi dengan mencari apa yang menjadi jati dirinya dan kemudian dikembangkan, serta buatlah klain berfikir bahwa diri anda pasti bisa, klain adalah seorang yang hebat. Jangan sampai klain mempertanyakan yang ada dalam dirinya seperti halnya, memiliki rasa bahwa saya tidak mampu, bahwa saya bodoh, dan apa kelebihan yang dimampunya.

\section{Daftar Rujukan}

Abdullah, Ridwan. Inovasi Pembelajran. Jakarta: Bumi aksara, 2013.

Ahmad, Syarwani. et al. "Desain Pembelajaran SMA Plus Negeri 2 Banyuasin III Berbasis Karakter di Era Masyarakat Ekonomi Asean”, Jurnal Kajian Ilmu Pendidikan, vol. 2, no. 2, 2017.

Ali, Moh. et al. Psikologi Remaja. Jakarta: Bumi Aksara, 2005.

Cahyani, Ine Agatha. Wawancara. Sidoarjo, Oktober 2018.

Dewantara, I Putu Mas. "Identifikasi Faktor Penyebab Kesulitan Belajar Keterampilan Berbicara Siswa dan Strategi Guru untuk Mengatasinya, Artikel Penelitian, Prodi Pendidikan Bahasa". Mei, 2012.

Hidayah, Anisa Ulifatun. Wawancara. Sidoarjo, Oktober 2018.

Hidayati, Sri Helma. "Peran Guru Bimbingan dan Konseling dalam Mengidentifikasi Permasalahan Belajar Peserta Didik di SMA Negeri Kandangan”, Jurnal Mahasiswa BK An-Nur: Berbeda, Bermakna, Mulia, vol. 3 no. 2, 2017.

Iqbal, Muhammad. "Hubungan antara Self Esteem dan Religiusitas terhadap Resiliensi pada Remaja di Yayasan Himmata". Skripsi--UIN Syarif Hidayatullah, Jakarta, 2011.

Ishtifa, Hanny. "Pengaruh Self - Efficacy dan Kecemasan Akademis terhadap Self Regulated Learning Mahasiswa Fakultas Psikologi Universitas Islam Negeri Jakarta". Skripsi--UIN Syarif Hidayatullah, Jakarta, 2011. 
Minarti, Eva Dwi. et al. "Studi Komperatif Penerapan Pendekatan Kontekstual dan Pendekatan Kontekstual Bersetting Pembelajaran Cooperative Script terhadap Kemampuan Representasi Matematis dan Self Confidence Siswa SMK di Kota Cimahi”, Jurnal Ilmiah UPT STKIP Siliwangi, vol. 2, no. 2, 2015.

Permata, Bunga. Wawancara. Sidoarjo, Oktober 2018.

Pratiwi, Dwi Astuti. "Pembelajaran Berbasis Masalah (Problem Base Learning) dengan Metode Proyek dan Reitasi Ditinjau dari Kreativitas dan Konsep Diri (Self Concept) Siswa". Tesis-Universitas Sebelas Maret, Surakarta, 2010.

Rahman, Rizqi. "Hubungan Self Concept terhadap Matematika dengan Kemampuan Berpikir Kreatif Matematika Siswa", Jurnal Ilmiah Program Studi Matematika STKIP Siliwangi Bandung, vol. 1, no. 1, 2012.

Rohayati, Iceu. Program Bimbingan Teman Sebaya untuk Meningkatkan Percaya Diri Siswa. Edisi Khusus no. 1, Agustus, 2011.

Yulianto, Fitri. "Kepercayaan Diri dan Prestasi Atlet Tae Kwon Do Daerah Istimewa Yogyakarta", Jurnal Psikologi Universitas Diponegoro. vol. 3, no. 1. 2006.

Yusuf, Syamu. Teori Kepribadian. Bandung: Reaja Rosdakarya, 2012.

Za'balawi (al), Sayyid. Pendidikan Remaja antara Islam dan Ilmu Jiwa, Abdul Hayyi al-Kattani. Depok: Gema Insani, 2007. 